日臨外会誌 $66(7), 1534-1539,2005$

原著

当院における十二指腸潰瘍穿孔保存的治療に対する クリニカルパスとその有用性の検討

\begin{tabular}{|c|c|c|c|c|c|c|c|c|c|c|c|}
\hline & & & 広島市 & 安仡 & j民病院夕 & 炓 & & & & & \\
\hline 部 & 龍太郎 & 平 & 林 直 & 樹 & 多幾山 & & 渉 & 山 & 本 & 英 & 喜 \\
\hline 谷 & 大 輔 & 嶋 & 田 徳 & 光 & 佐 藤 & 幸 & 雄 & 佐 & 伯 & 修 & \\
\hline 田 & 秀 則 & 山 & 下 芳 & 典 & 久松 & 和 & 史 & & & & \\
\hline
\end{tabular}

当科で施行している十二指腸溃瘍穿孔保存的治療に対するクリニカルパス (CP)の妥 当性，有用性を検討した．当科では平成13年 8 月より十二指腸潰瘍穿孔に対する保存的 治療を開始し，良好な結果を得てきた。これらのデータに基づいて平成15年 4 月に十二 指腸潰瘍穿孔保存的治療に対するCP を作成し，現在までに10例に対して運用してきた。 本稿では CP 䢝入前後の比較を行い, バリアンスに関して要因別に検討した. CP 導入前 後で治療経過に大きな差は認められなかったが, CP 導入後は入院期間が短縮し入院医 療費が減少する傾向があった. $\mathrm{CP}$ 導入後, 重篤な合併症や手術への移行は経験しておら ず、バリアンスは許容できるものであった，当科の十二指腸浿瘍穿孔保存的治療に対す るCP は妥当なもので, 治療法の開示と標準化, 簡略化を図る上で $\mathrm{CP}$ 導入の効果は大き いと考えられた。

真引用語：十二指腸潰瘍穿孔, 腹膜炎, 保存的治療, クリニカルパス

\section{緒 言}

十二指腸謴瘍穿孔に対する保存的治療は, $\mathrm{H}_{2}$ 受容体 拮抗薬やプロトンポンプ阻害薬の導入によって1990年 代後半から急速に広まっている ${ }^{122}$. 当科ではプロトン ポンプ阻害薬の注射郕が保険適応になった後の平成13 年 8 月上り十二指腸謴場穿孔に対する保存的治療を開 始し，それ以前の腹腔鏡下大網充垣術を施行した症例 と比較して遜色ない結果を得てきた。これらのデータ に基づいて平成15年 4 月に十二指腸滍境穿孔保存的治 療に対するクリニカルパス (CP) を作成し運用してき た. 本稿では $\mathrm{CP}$ 導入前後の症例を比較し,バリアンス 分析に基づき CP の妥当性, 有用性について検討した ので報告する。

\section{方 法}

平成13年 8 月から平成16年 8 月までに当科にて十二 指腸潰瘍穿孔と診断し治療を行った 36 例のうち, 保存 的治療を施行した29例を対象とした. CP 導入前の19

2004 年11月25日受付 2005年 4 月20日採用 〈所属施設住所〉

干731-0293 広島市安佐北区可部南 2-1-1
例を $\mathrm{NCP}$ 群, $\mathrm{CP}$ 導入後の10例を $\mathrm{CP}$ 群とし, retrospectiveに比較検討した。またCP のバリアンスに関 して要因別に検討した。

十二指腸浿愓穿孔の診断方法, 保存的治療の適応基 準, 保存的治療 CP の内容は以下に示した。

1. 十二指腸潰瘍穿孔の診断方法

単純X線または CTにて腹腔内遊離ガス像の存在を 確認し上部消化管穿孔が疑われる症例に対して, 全例 に緊急上部消化管内視鏡を施行し十二指腸潰瘍穿孔と 診断した，同時に穿孔部位および穿孔径の確認を行っ た.

\section{2. 保存的治療の適応基準}

(1)年齢が65歳未満

(2)重篤な基礎疾患がない (ASA 分類：Class 1)

(3) CT にて大量の腹水を認めない

(4)上部消化管内視鏡にて穿孔径が $5 \mathrm{~mm}$ 程度までで 幽門狭窄を認めない

以上を原則とし，最終的には主治医の判断で治療方 法を選択した。

3. 保存的治療 CP の内容（表 1)

(1)絶飲食（経鼻胃管による胃内容減圧は行わない） 
表 1 保存的治療クリニカルパス

\begin{tabular}{|c|c|c|c|c|c|c|}
\hline \multicolumn{7}{|c|}{ 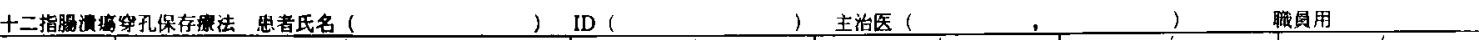 } \\
\hline \multirow{2}{*}{ 日時 } & \multirow{2}{*}{\multicolumn{2}{|c|}{\begin{tabular}{l}
\multicolumn{1}{c}{$/$} \\
入院日 (入院後)
\end{tabular}}} & \multicolumn{2}{|r|}{1} & \multirow[b]{2}{*}{ 入院 4日目 } & \multirow{2}{*}{\begin{tabular}{r|}
\multicolumn{1}{|l}{} \\
入院 5 日目 \\
\end{tabular}} \\
\hline & & & 入院 2 日目 & 入院 3 日目 & & \\
\hline 模查 & 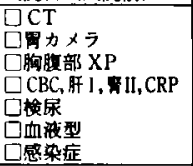 & 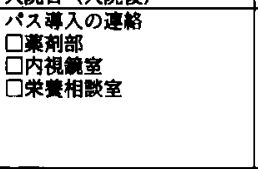 & 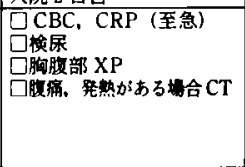 & 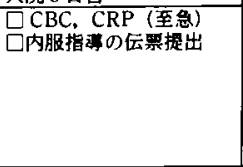 & $\square \mathrm{CBC}, \mathrm{CRP}$, 訮 I, R II & \\
\hline 治荧，莱詴 & $\begin{array}{l}\square \text { Veen } \begin{array}{c}\text { F } 500 \mathrm{ml} \\
\text { でイン確保 }\end{array}\end{array}$ & 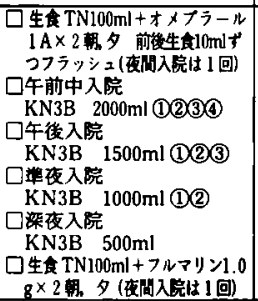 & 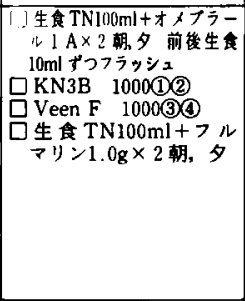 & 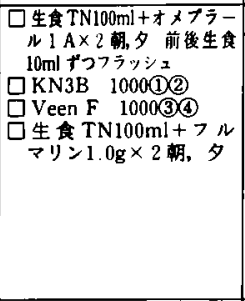 & 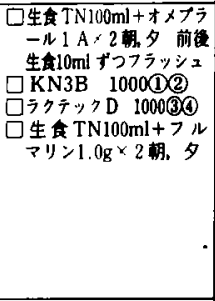 & $\begin{array}{l}\text { 口KN3B } 1000 \text { (1)(2) } \\
\text { 口ラクテックD } 1000 \\
\text { (34)(口ック (OK) } \\
\text { 口内服開始 (PPI) }\end{array}$ \\
\hline 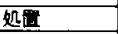 & & 口央痛時指示 & & & & \\
\hline 安静度 & & ロフリー & ロフリー & Øフリー & ロフリー & 口フリー \\
\hline 英事 & 口絶飲食 & 口絶的食 & 口䎦䣄 & $\square$ 絶故食 & $\begin{array}{c}\text { 口排ガスあれば㐸水可 } \\
\text { なければ絶觓令 }\end{array}$ & 口排カスちれは做水可 \\
\hline 站里 & & & 口点䈐ロックしてシャクー可 & 口点商ロックしてシャワー可 & 口点㵝口ックしてシャクー可 & $\square$ 口浴可 \\
\hline 説明，指要 & & 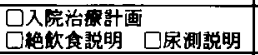 & & 口可能な限り歩行促す & & 口内服指立 \\
\hline 涀察項目 & & 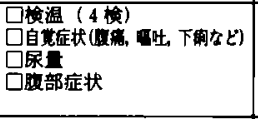 & 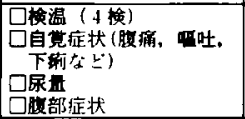 & 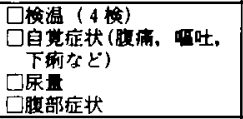 & 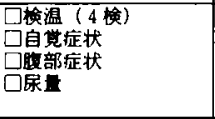 & 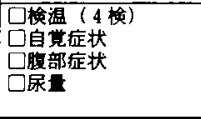 \\
\hline アウトカム & & 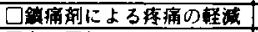 & & & & 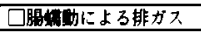 \\
\hline バリアンス & & 口有・口無 & 口有. “無 & 吕有・回無 & 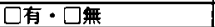 & $\square$ 口有·口無 \\
\hline バリフンス内容 & & & & & & \\
\hline 䨌顽師的 & & & & & & \\
\hline
\end{tabular}

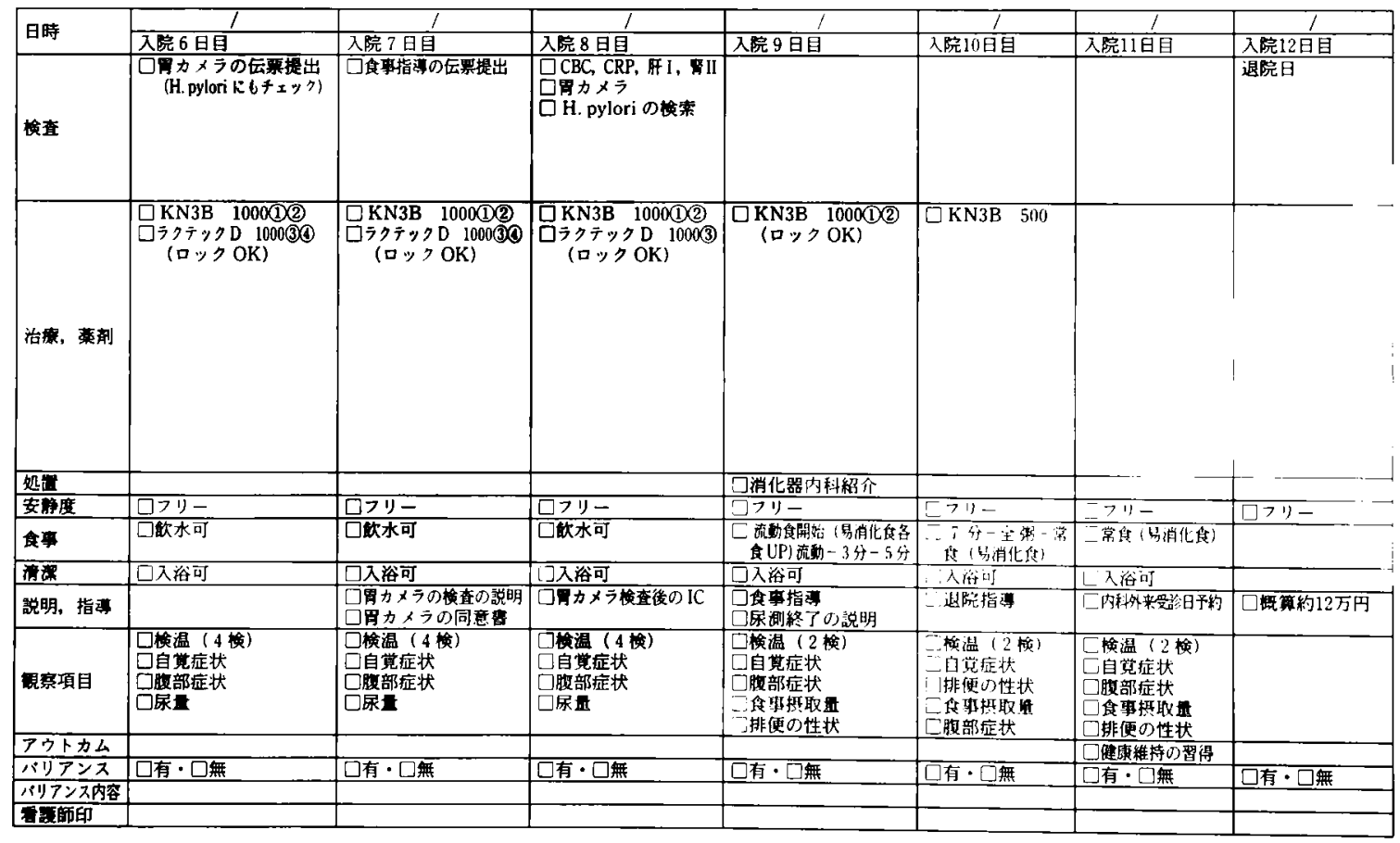

(2)抗生郕（Flomoxef $2 \mathrm{~g}$ /day）静注 4 日間

(3)プロトンポンプ阻害薬 (Omeprazole 40mg/day)
静注 4 日間

(4) 5 日目より飲水開始, プロトンポンプ阻害薬内服 
表 2 患者背景

\begin{tabular}{|c|c|c|c|}
\hline & NCP 群 & $\mathrm{CP}$ 群 & $p$ 值 \\
\hline 症例数 & 19例 & 10例 & \\
\hline 年糍 & $42.2(17 \sim 74)$ & $39.9(19 \sim 63)$ & N.S \\
\hline 性差（男：女） & $18: 1$ & $10: 0$ & N. S \\
\hline 発症からの時間（時間） & $8.8 \pm 11.1$ & $3.4 \pm 3.3$ & $p<0.05$ \\
\hline 治療前体温 $\left({ }^{\circ} \mathrm{C}\right)$ & $37.3 \pm 0.7$ & $37.7 \pm 0.9$ & N. S \\
\hline 治療前 WBC $\left(/ \mathrm{mm}^{3}\right)$ & $14,006 \pm 6,159$ & $12.595 \pm 4.002$ & N.S \\
\hline 手術移行 & 2 例 $(11 \%)$ & 0 例 $(0 \%)$ & N. S \\
\hline 局麻下ドレナージ & 2 例 $(11 \%)$ & 1 例 $\left(10^{\circ}\right)$ & N.S \\
\hline
\end{tabular}

表 3 治療経過

\begin{tabular}{c|c|c|c}
\hline & NCP 群 & CP 群 & $p$ 值 \\
\hline 步行開始病日 & $2.1 \pm 2.1$ & $1.9 \pm 1.4$ & N. S \\
抗生都使用期間 & $4.8 \pm 2.7$ & $4.3 \pm 1.3$ & N.S \\
饮水開始病日 & $5.8 \pm 2.1$ & $5.0 \pm 5.6$ & $p<0.05$ \\
食事開始病日 & $7.6 \pm 1.7$ & $9.1 \pm 4.6$ & N. S \\
入院期間 & $15.1 \pm 6.2$ & $14.1 \pm 7.4$ & N. S \\
\hline
\end{tabular}

開始

(5) 8 日目に上部消化管内視鏡にて穿孔部の閉鎖を確 䜑，同時に Helicobacter pylori の検索

(6) 9 日目より食事開始

(7)12日目に退院

(8)退院後は内科通院（除菌，謴愓の治療など）

なお, 統計学的有意差検定は Mann-Whitney U 検 定および $\chi 2$ 乗検定を用いて行い, $p<0.05$ を有意差あ りと判定した。

\section{結 果}

\section{1. 患者背景}

CP 導入前は 25 例中 19 例 (76\%) に保存的治療が施行 され，6例 (24\%) に緊急手術が施行された。一方 $\mathrm{CP}$ 導入後は11例中 10 例 $(91 \%)$ に保存的治療 (CP) が施 行され，1例（9\%）に緊急手術が施行されたＮCP 群, $\mathrm{CP}$ 群の両群間で年齢, 性別, 治療開始前体温, 治 療開始前 WBC に有意差は認めなかった，発症から治 療開始までの時間は CP 群で有意に短かった。 NCP 群 では19例中 2 例で保存的治療が奏効せずに手術に移行 したが,CP群では手術移行はなかった。またNCP群で 2 例，CP群で 1 例に局麻下ドレナージを要した(表 2 )。

\section{2, 治療経過}

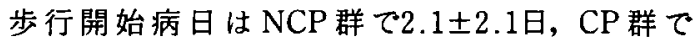
$1.9 \pm 1.4$ 日であった。抗生剤使用期間は NCP 群て $4.8 \pm 2.7$ 日, CP 群で $4.3 \pm 1.3$ 日であった. 飲水開始病

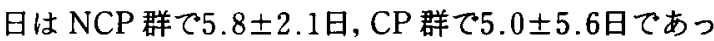

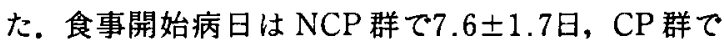

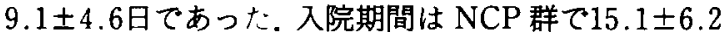

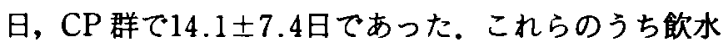
開始病日にのみ有意差を認めた（表 3 ）。

\section{3、医癔費}

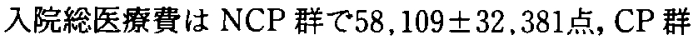
で44,963士21,596点で, CP 導入後は减少傾向にあっ たが有意差は認めなかった，保存的治療非奏効例（手 術移行または局麻下ドレナージ)も含めて 200,000 点以 上の高額医療費症例はなかった。

\section{4. バリアンス分析}

$\mathrm{CP}$ に抢ける抗生剤種類, 抗生剤投与期間, 絶飲期 間, 絶食期間, 輸液変更, 入院期間の 6 項目について 負のバリアンスを分析した。抗生剤種類の変更は 4 例 に認められたが, 治療の遷延によるものは1例のみで， 3 例は主治医の指示変更によるものであった。抗生郕 投与期間の延長，絶飲期間の延長はそれぞれ 1 例に䛱 められ，治療の遷延が原因であった。絶食期間の延長 は 3 例に認められたが，1例は主治医の指示の遅れに よるもので，治療の遷延によるものは2例であった。 輸夜の変更は 2 例に認められ，いずれも治療の遷延か 原因であった，入院期間の延長は10例中 4 例に認めら れた. すなわち治療の遷延によるものが 2 例（逸脱）， 主治医の指示の遅れによるものが 1 例, 病院のシステ 
表 4 クリニカルパスの負のバリアンス

\begin{tabular}{|c|c|c|}
\hline バリアンス項目 & パリアンス要因 & 件数 \\
\hline \multirow[t]{2}{*}{ 抗生㧩種類変更 } & 治療の還延 & 1 \\
\hline & 主治医の指示変更 & 3 \\
\hline 抗生嵃投与期間 & 治療の遷延 & 1 \\
\hline 絶飲期間 & 治療の遷延 & 1 \\
\hline \multirow[t]{2}{*}{ 絶食期間 } & 治療の遷延 & 2 \\
\hline & 主治医の指示幄れ & 1 \\
\hline 輸液変更 & 治療の僄延 & 2 \\
\hline \multirow[t]{3}{*}{ 入院期間 } & 治療の還延 & 2 \\
\hline & 主治医の指示痋れ & 1 \\
\hline & 病院のシステム & 1 \\
\hline 計 & & $15 / 60(25 \%)$ \\
\hline
\end{tabular}

表 5 パリアンスの要因

\begin{tabular}{c|c}
\hline バリアンス要因 & 件数 \\
\hline 患者 & $9(60 \%)$ \\
医療スタッフ & $5(33 \%)$ \\
病院システム & $1(7 \%)$ \\
\hline 計 & 15 \\
\hline
\end{tabular}

ム（土曜日，日曜日の退院ができない）によるものが I例であった，全体としてのバリアンスの頻度は $25 \%$ (60件中15件)であった（表 4)。 バリアンスの要因か らみると, 患者の要因が 9 件 $(60 \%)$, 医療スタッフの 要因が 5 件 (33\%), 病院システムの要因が 1 件 $(7 \%)$ であった(表 5 )。

\section{考察}

十二指腸潰瘍穿孔は1980年代までは絶対的手術適応

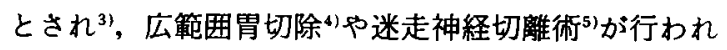
てきた. その後 $\mathrm{H}_{2}$ 受容体拮抗薬やプロトンポンプ阻 害薬の运入に伴い, 腹膜炎の治療のみを外科的に行い, 潰場の治療は薬物によって行う穿孔部閉鎖術や大網充 填術が行われるようになっだ.

一方，十二指腸謴場穿孔に対する保存的治療は 1935 年の Wangensteen ${ }^{7} や 1957$ 年の Taylor ${ }^{8}$ の報告に始 まり, 本邦でも1980年代後半から保存的治療に関する 報告9110)が散見されるようになった。1990年代後半か らは積極的に保存的治療を選択する施設が増加し, 保

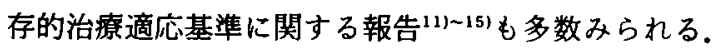
近年では CP の急速な普及に伴い，十二指腸謴瘍穿孔 に対する CP を荨入する施設も出てきている(16)17.

当科では平成 13 年 7 月までは十二指腸潰㰾穿孔に対 して腹腔鏡下大網充埧術を施行してきたが,プロトン
ポンプ阻害薬の注射剤が保険適応になった後の平成 13 年 8 月より保存的治療を開始した。当初から適応基準 を設定していたが，主治医の判断で緊急手術を施行し た症例が $24 \%$ あった。手術移行症例や局麻下ドレナー ジを要した症例も認められたが，全体としては緊急手 術を施行した症例と比較して，入院期間や合併症，医 療費などにおいて遜色ない結果を得てきた。これらの データに基づいて平成15年 4 月に十二指腸潰場穿孔保 存的治療に対するCP を作成し運用してきた.

まず十二指腸謴犜穿孔の確定診断を得るために, 単 純 $\mathrm{X}$ 線や CTにて腹腔内遊離ガス像を認め上部消化管 穿孔が疑われる症例に対しては，全例に緊急上部消化 管内視鏡を施行し穿孔部の確認を行うこととした．上 部消化管穿孔に対する内視鏡検査は，被覆された穿孔 部を再穿孔させて腹膜炎を增悪させる可能性があると いう報告 ${ }^{18)}$ もあるが, 近年では検查時の送気を最小限 にとどめれば腹膜炎の増悪はないという報告 ${ }^{141199}$ が多 く, 小川ら"1)の手術症例49例の検討でも術前内視鏡施 行例と非施行例に差はなかったと報告されている。当 科でも保存的治療開始当初より全例に㗨急内視鏡検査 を施行し有益な情報を得ており，大きな問題は発生し ていない.

保存的治療の適応基準としては，重篤な合併症がな く全身状態が安定していること, 腹膜刺激症状が上腹 部に限局していること, 腹水貯留が上腹部に限局して いることなどが報告されている(114115). 発症からの経 過時間については10〜12時間以内に制限している報 告 ${ }^{1113)}$ もあるが，報木ら告では他の条件が良け れば経過時間にはこだわらないとしている．また大森 ら"は適応を拡大して65歳未満は全例保存的治療の適 応としている．われわれの適応基準は今回の検討でバ 
表 6 クリニカルパス適応症例

\begin{tabular}{|c|c|c|c|c|c|c|c|c|c|c|}
\hline No & 年龄 & 性別 & 抗生䍑種類・ & 抗生烱期間 & 絶飲期間 & 絶食期間 & 輸液変更 & 入院期間 & 合併症 & ドレナージ \\
\hline 1 & 29 & 男 & $\mathrm{CMZ}$ & 3 & 3 & 8 & $(-)$ & 12 & $(-)$ & $(-)$ \\
\hline 2 & 45 & 男 & FMOX & 4 & 4 & 9 & $(-)$ & 13 & $(-)$ & $(-)$ \\
\hline 3 & 27 & 男 & FMOX & 4 & 3 & 8 & $(-)$ & 15 & $(-)$ & $(-)$ \\
\hline 4 & 19 & 男 & $\mathrm{CMZ}$ & 4 & 4 & 8 & $(-)$ & 12 & $(-)$ & $(-)$ \\
\hline 5 & 33 & 男 & FMOX, MEPM & 8 & 21 & 21 & $(+)$ & 34 & 右横隔膜下滕㾖 & $(+)$ \\
\hline 6 & 31 & 男 & $\mathrm{CMZ}$ & 4 & 3 & 6 & $(-)$ & 10 & $(-)$ & $(-)$ \\
\hline 7 & 56 & 男 & FMOX & 4 & 3 & 7 & $(-)$ & 9 & $(-)$ & $(-)$ \\
\hline 8 & 37 & 男 & FMOX & 4 & 3 & 6 & $(-)$ & 10 & $(-)$ & $(-)$ \\
\hline 9 & 63 & 男 & FMOX & 4 & 3 & 6 & $(-)$ & 10 & $(-)$ & $(-)$ \\
\hline 10 & 59 & 男 & FMOX & 4 & 3 & 12 & $(+)$ & 16 & $(-)$ & $(-)$ \\
\hline
\end{tabular}

'CMZ : Cefmetazole, FMOX : Flomoxef, MEPM : Meropenem

リアンスの発生が少なく適切な基準と思われるが, 適 応払大は症例を重なて再検討し，慎重にすべきである と考えている.

十二指腸潰瘍穿孔保存的治療の CP の報告は少ない が, 石倉 ${ }^{16)}$ は 4 日間の経鼻胃管からの持続吸引減圧, 1 週間の絶飲食, 内視鏡再検後の食事開始, 15日間の入 院などを設定した CP を報告している. 保存的治療に

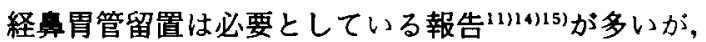
当科ではプロトンポンプ阻害薬の静注を行えば胃内容 の堿圧は必要ないと考え, CP 導入前から経章胃管留 置は行わずに良好な結果を得てきた。 また輸夜は末梢 輸液のみとし，絶飲期間を短くすることで患者の負担 がより少ない治療を心がけている。

今回の比較検討では患者背景において，NCP 群と CP 群で発症から治療開始までの時間に有意差を認め た.これはNCP 群に発症後 1 ～2 日経過してから受 診した症例が 2 例含まれていたためである。この 2 例 はいず机も保存的治療が奏効し軽快しており，12時間 以上経過した症例でも, 受診時にすでに被覆穿孔の状 態であると考えられる場合は保存的治療の適応になる と思われる.治療経過に関しては, NCP 群と CP 群で 飲水開始病日のみに有意差を認めた。 CP 導入前は飲 水開始基準が不明確で主治医により個々に判断されて いたが，CP導入により早期に飲水を開始しても問題 ないという明確な基準ができた結果と考えられる。そ の他の比較では有意差は認められないが, 緊急手術を 選択した症例が減少したこと，入院期間が短縮し医療 費が減少したこと，治療方針が明確となり主治医によ る治療の格差がなくなったことなど CP 導入の効果は
十分にあると考えている。

CP のバリアンス分析では，負のパリアンス(パスの 進行の遅れ）が25\%（60件中15件）に䍿められた。 のうち患者の要因 (治療の遷延)によるものは 9 件 (60 \%)であった．本来バリアンスは変動と逸脱に細分化 されると言われ，救急疾患を対象とした CP の場合に は全体の進行自体に大きく影響を及ほさない程度の変 動はバリアンスとみなさなくてもよいという意見があ $3^{16)}$. 今回の CP 適応患者のうち逸脱に該当する症例 は，右横隔膜下膿演を合併し局麻下ドレナージを施行 した症例と，内視鏡再検にて穿孔部の閉鎖が不十分て 食事開始を遅らせた症例の 2 例のみで，その他の症例 のバリアンスは変動に該当すると考えられる（表 6). 保存的治療奏効率は $90 \%, \mathrm{CP}$ 完遂率は $80 \%$ でり, 現 行の CP は適応基準，治療内容とも概ね許容できるも のであると考えている。

現行の CP は初版のものであり,抗生剤の変更(第一 世代セフェム系)，絶食期間の短縮，入院期間の短縮な ど改良の余地があると考えている.今後症例を重ねて CP を再評価し改良していくことにより，さらに治療 の簡略化が図られ，医療費の削減につながると考えら れる。

\section{結 語}

急性疾患である十二指腸謴瘍穿孔保存的治療に対す るクリニカルパスを作成し運用したが，大きな問題な く使用することができた。治療経過や医療費の面で有 意な差として現れてはいないが，治療法の開示と標準 化，簡略化を図る上でクリニカルパス導入の効果は大 きいと考えられた。 


\section{文献}

1）大森浩明, 旭 博史, 井上義博他: 保存的治療を 中心とした穿孔性十二指腸溃癌に対する治療指 針. 日腹部救急医会誌 $16: 641-648,1996$

2）山成英夫, 島山俊夫，竹智義臣他：十二指腸潰痬 穿孔に対する保存的治療の検討. 臨外 $51: 1337$ $-1341,1996$

3）青木照明：胃・十二指腸潰瘍の絶対的手術適応例 に対する術式. 手術 $38: 143-151,1984$

4) 原川伊寿, 蜂須賀喜多男, 山口晃弘他：胃・十二 指腸湞疸の穿孔の295例の検討一広範囲胃切除術 を中心として一腹部救急診療の進歩 $6: 413$ 418, 1986

5）中越 享, 三浦敏夫，中尾治彦他：十二指腸潰場 穿孔に対する迷走神経切離術の検討. 日消外会誌 $21: 1043-1049,1988$

6）柴多三省, 熊井浩一郎, 大上正裕地：消化性謴痀 手術症例の年次的推移と十二指腸潰瘍穿孔に対す る治療の変遷. 腹部救急診療の進步 $12: 833-$ 837,1992

7) Wangensteen $\mathrm{OH}: \mathrm{Non}$-operative treatment of localized perforations of the duodenum. Minn Med 18:477-480, 1935

8) Taylor $\mathrm{H}$ : Guest lecture: The non-surgical treatment of perforated peptic ulcer. Gastroenterology $33: 353-368,1957$

9）竹末芳生, 横山 隆, 児玉 節他: 胃十二指腸穿 孔の検討一消化性潰瘍穿孔例における手術適応に ついて一。目臨外会誌 $47: 1557-1562,1986$
10）村田修一, 清崎克美, 若狭林一郎他：十二指腸溃 瘍穿孔の保存的治療. 外科 $49: 495-498,1987$

11）小川不二夫, 福島亮治, 稲葉 琼他: 十二指腸潰 瘍穿孔例に対する保存的治療の prospective study. 日腹部救急医会誌 $23: 859-864,2003$

12）井上暗, 梅北信孝, 宮本幸雄他: 胃, 十二指腸 潰瘍穿孔に対する保存的治療法の適応について。 日臨外会誌 $64: 2665-2670,2003$

13）富田凉一, 藤崎 滋, 池田太郎他：十二指腸潰湯 穿孔に対する保存的治療の適応基準に関する検 討. 日外科系連会誌 $26 ： 1403-1406,2001$

14）城野晃一, 岡内 博, 甲原純二他：胃十二指腸謴 瘍穿孔症例に対する保存的治療の険討. 京都医会 誌 $46: 123-126,1999$

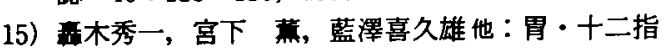
腸潰瘍穿孔に対する保存的治療. 日外科系連会誌 $29: 18-24,2004$

16）石倉宏恭：特集 救急医療とクリニカルパス 胃・十二指腸潰瘍穿孔とクリニカルパス. 救急医 $26: 926-931,2002$

17）津村裕昭, 市川 徹, 香河哲也他: 穿孔性十二指 腸溃瘍治療法選択クリニカルパスの試行と有用 性. 外科 $66: 34-39,2004$

18）三浦宏二, 高野征雄, 飯沼泰史他：十二指腸海㿋 穿孔に対する積極的な保存的治療. 腹部救急診療 の進歩 $12: 863-868,1992$

19）大森浩明, 昍 博史, 井上義博他：胃・十二指腸 穿孔に対する保存療法の有用性. 外科治療 86 ： $1119-1120,2002$

\title{
VALIDITY AND EFFECTIVENESS OF CLINICAL PATHWAY IN CONSERVATIVE TREATMENT FOR PERFORATED DUODENAL ULCER
}

\author{
Ryutaro SAKABE, Naoki HIRABAYASHI, Wataru TAKIYAMA, Hideki YAMAMOTO, \\ Daisuke SUMITANI, Norimitsu SHIMADA, Yukio SATO, Shuji SAEKI, \\ Hidenori MUKAIDA, Yoshinori YAMASHITA and Kazufumi HISAMATSU \\ Department of Surgery, Hiroshima City Asa Hospital
}

In this study, we examined the validity and effectiveness of clinical pathway (CP) in conservative treatment for perforated duodenal ulcer (DU). We retrospectively analyzed 19 consecutive cases of perforated DU treated with conservative therapy from August 2001 to March 2003 in our institute. Based on these experiences, $\mathrm{CP}$ in conservative treatment for perforated $\mathrm{DU}$ was proposed and has been applied to 10 cases since April 2003. We made a comparative study on the patient's outcome between non $\mathrm{CP}$ group and $\mathrm{CP}$ group, and also investigated the causes of variances in $\mathrm{CP}$ group in detail. Although there was no significant difference between two groups, there was a tendency of shorter hospital stay and less medical expenses in $\mathrm{CP}$ group. There was no major complications, no conversion to operation and minimal variances in $\mathrm{CP}$ group. From the above-mentioned results, we conclude that our $\mathrm{CP}$ in conservative treatment for perforated DU is valid, which in turn would results in standardization, simplification and exhibition of perforated DU treatment. 